\title{
A high-resolution multi-proxy record of late Cenozoic environment change from central Taklimakan Desert, China
}

\author{
X. Wang, D. H. Sun, F. Wang, B. F. Li, S. Wu, F. Guo, Z. J. Li, Y. B. Zhang, and F. H. Chen \\ Key Laboratory of Western China's Environmental Systems (Ministry of Education), Lanzhou University, \\ Lanzhou, 730000, China
}

Correspondence to: D. H. Sun (dhsun@lzu.edu.cn)

Received: 6 May 2013 - Published in Clim. Past Discuss.: 24 May 2013

Revised: 16 October 2013 - Accepted: 5 November 2013 - Published: 6 December 2013

\begin{abstract}
The Taklimakan Desert in the Tarim Basin is the largest desert in Central Asia, and is regarded as one of the main dust sources to the Northern Hemisphere. Late Cenozoic sedimentary sequences with intercalated in-situ aeolian dune sands in this area preserve direct evidence for the Asian desertification. Herein, we report a high-resolution multiproxy climatic record from the precise magnetostratigraphic dated Hongbaishan section in the central Taklimakan Desert. Our results show that a fundamental climate change, characterised by significant cooling, enhanced aridity, and intensified atmospheric circulation, occurred at $2.8 \mathrm{Ma}$. Good correlations between paleo-environmental records in the dust sources and downwind areas suggest a broadly consistent climate evolution of northwestern China during the late Cenozoic, which is probably driven by the uplift of the Tibet Plateau and the Northern Hemisphere glaciation.
\end{abstract}

\section{Introduction}

The progressive retreat of the Tethys Sea and the stepwise uplift of the Tibetan Plateau during the Cenozoic resulted in the aridification and desertification in the Asian interior (e.g. Ramstein et al., 1997; Zhang et al., 2007; Manabe and Broccoli, 1990; Kutzbach et al., 1993; Ding et al., 1995; An et al., 2001; Lu et al., 2010; Molnar et al., 2010; Miao et al., 2012). These events led to the formation of large deserts in northwestern China and the accumulation of aeolian deposits in the downwind areas of the Chinese Loess Plateau (CLP) and the North Pacific (NP) (e.g. Liu, 1985; Rea et al., 1985).

Through study of the sedimentary sequences from the eastern CLP and NP, it is apparent that the desertification in the
Asian interior initiated at 7-8 Ma (e.g. Sun D. et al., 1998; Ding et al., 1999; An et al., 2001), and enhanced at 3.4, 2.8, 1.8, 1.2, and 0.6 Ma (e.g. Sun and An, 2005; Sun D. et al., 2008). The recent discovery of the Miocene loess sequences from the western CLP and its western areas extended the Chinese dust history back to 25-22 Ma (e.g. Guo et al., 2002; Sun J. et al., 2010; Qiang et al., 2011). However, the aeolian records from the NP showed that aeolian deposits existed across the entire Cenozoic, exhibiting stepwise increases in the mass accumulation rate, and suggesting progressively enhanced aridity in the source regions (e.g. Rea et al., 1985, 1998). To obtain more direct evidence for the Asian aridification and desertification, a better knowledge of the Cenozoic sedimentary records from the source regions is essential.

The Taklimakan Desert in the Tarim Basin, with an area of $337000 \mathrm{~km}^{2}$, is the largest and oldest desert in Central Asia (Zhu et al., 1980), and is regarded as one of the main dust sources of the Northern Hemisphere (e.g. Washington et al., 2003; Zhang et al., 2003; Chen and Li, 2011). In the central Taklimakan Desert, continuous late Cenozoic sequences with intercalated in-situ aeolian dune sand preserve direct evidence for the Asian desertification. In this work, we report the multi-proxy indices of the Hongbaishan Section (hereafter refer to HBS Section), namely mean size, the ultrafine component proportion, color reflectance, magnetic susceptibility, and frequency-depended magnetic susceptibility, based on the chronological frame established by paleomagnetic and ESR dating of two parallel sections (i.e. HBS and Mazhatagh Section) (Sun D. et al., 2011a). We attempt to provide the unique high-resolution multi-proxy paleoenvironmental records for the dust source region during 4.2 to $0.99 \mathrm{Ma}$. 


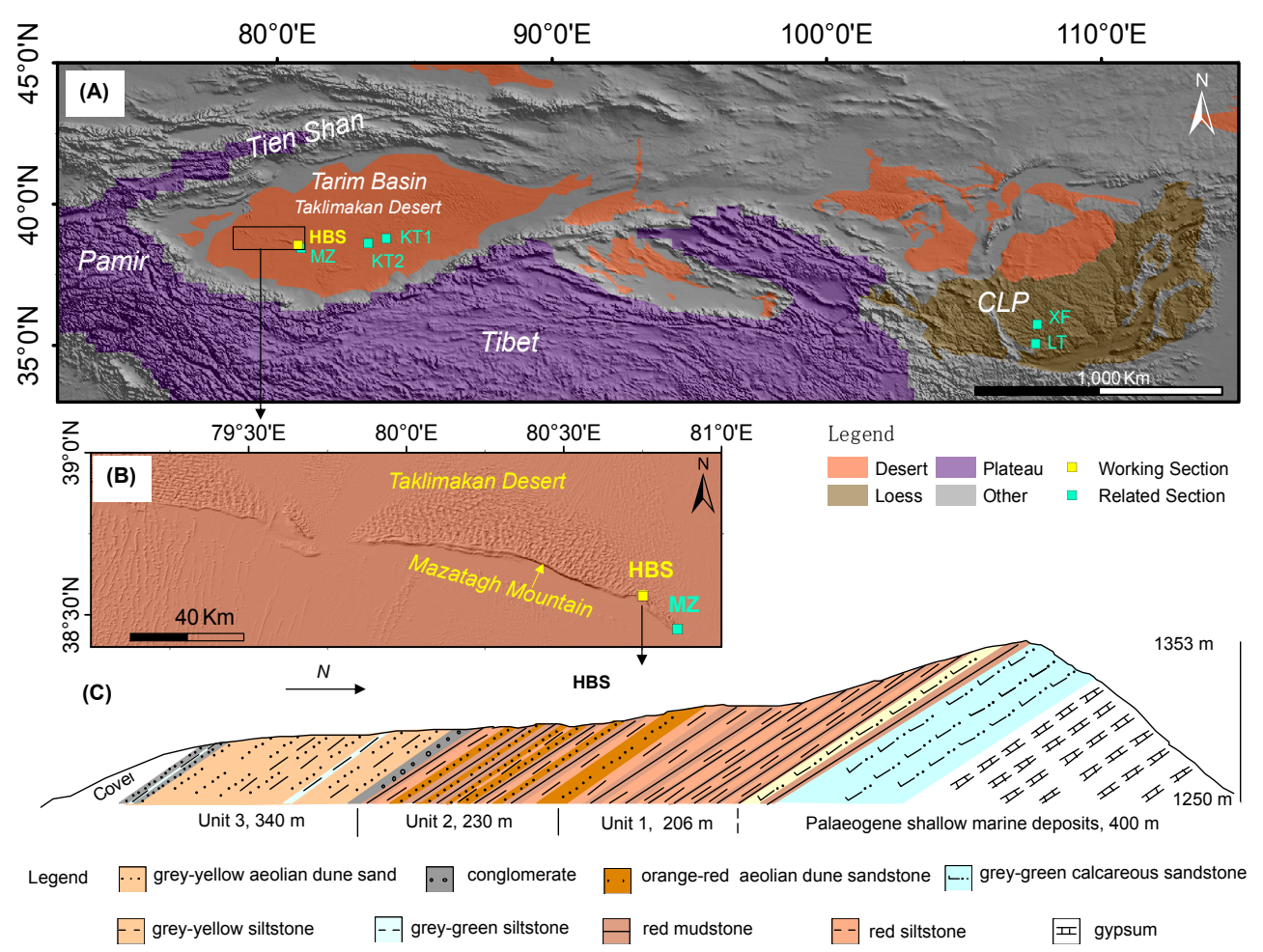

Fig. 1. Topography of northwestern China projected on digital elevation model (A) location of the Mazhatagh Mountain (B), and schematic geological section of the HBS Section (C).

\section{Geological setting and methods}

The Tarim Basin is one of the largest closed basins on earth, which is bounded by the Tibet Plateau to the south, the Pamir Mountains to the west, and the Tien Shan Mountains to the north. The landform of the Tarim Basin is characterised by high mountains and alluvial fans at its periphery, and expansive flat sand sea (the Taklimakan Desert) in the central region (Fig. 1a). Nevertheless, $\sim 240 \mathrm{~km}$ east-west ward mountains were developed in the central Taklimakan Desert in response to the India-Asia collision, from where the Cenozoic sedimentary sequences cropped out (Fig. 1b).

Lying in the rain shadow of the Tibet Plateau, the climate of the Taklimakan Desert is extremely dry. The mean annual precipitation is less than $50 \mathrm{~mm}$, whereas the mean annul evaporation is more than $2000 \mathrm{~mm}$ (Zhu et al., 1980), making it one of the driest desert on earth. Dominated by the Westerlies, the region prevails northeasterly wind, which generates frequent storms at most time of the year (Aoki et al., 2005).

The HBS Section $\left(38^{\circ} 33^{\prime} 33^{\prime \prime} \mathrm{N}, 80^{\circ} 43^{\prime} 35^{\prime \prime} \mathrm{E}\right)$ is located at the eastern segment of the Mazatagh Mountain (Fig. 1b). The stratigraphic sequence is composed of the Paleogene shallow marine succession and the Neogene nonmarine strata (Fig. 1c), which are separated by a significant sedimentary hiatus (Yong et al., 1983). In this study, we focus on the continental succession, which is subdivided into three units (Fig. 2) according to the lithology, sedimentary fa-

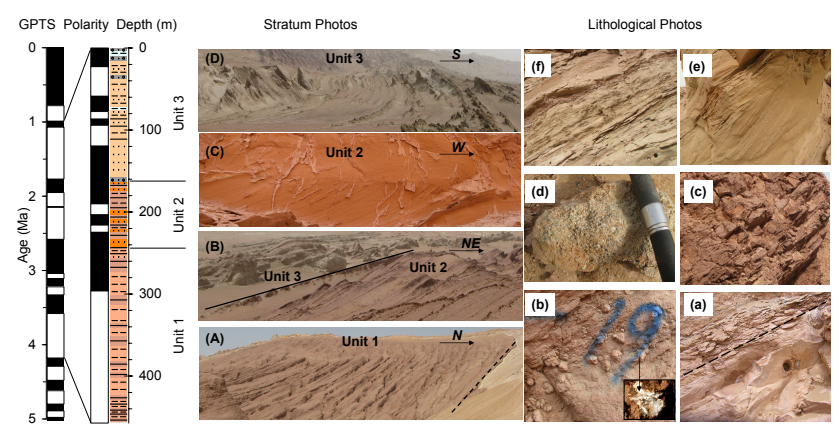

Fig. 2. Stratigraphy and magnetostratigraphy (Sun D. et al., 2011a) of the HBS Section. The lithology types of the strata are the same as in Fig. 1.

cies, and proxy indices. Unit 1 (457-241 m interval), disconformably overlying the Paleocene marine strata, is about $216 \mathrm{~m}$ of interbedding of reddish siltstone and red mudstone (Fig. 2a); occasionally, it contains reddish fine sandstone layers. Red mudstone in this unit is characterised by thin horizontally stratified intercalated with several thin greygreen layers, whereas reddish fine sandstone is characterised by thick horizontal beddings with ripples (Fig. 2a), indicative of ephemeral fluvial and lacustrine facies association on the whole (e.g. Picard and High, 1981; Boggs, 1995; Reading, 1996). However, a large portion of reddish siltstone 
prevails in Unit 1. These deposits are well-sorted with massive structure, exhibiting similar sedimentological characters with red clay deposits from the CLP, and suggesting these are aeolian dust deposits. In addition, thin-bedded gypsum and gypsum nodules (Fig. 2b) commonly occurred in the fluvial-lacustrine strata, reflecting high evaporation rate, and thus, hot and dry environment when the rock was formed. Unit 2 (241-153 m interval) comprises about $84 \mathrm{~m}$-thick alternation of reddish-orange fine sandstone, reddish siltstone, and deep-red laminated mudstone (Fig. 2b). Reddish-orange fine-grained sandstone in this unit is well-sorted and poorlycemented with large-scale cross-beddings (Fig. 2c), suggesting in-situ aeolian dune sand (e.g. Pye and Tsoar, 2009; Sun D. et al., 2011a). Reddish siltstone and red mudstone (Fig. 2c) show similar sedimentological characters and facies with those of Unit 1. Unit 3 (153-0 m interval), with a thickness of more than $153 \mathrm{~m}$, is mostly grey-yellow fine sandstone and siltstone intercalated with grey-yellow and greygreen mudstone (Fig. 2d). The base of unit 3 is a yellowish sandy-gravel layer (Fig. 2d), which is interpreted as fluvial facies (Sun D. et al., 2011a). Grey yellow fine sandstone layer is poorly-cemented and well-sorted with large-scale crossbeddings (Fig. 2e), whilst, grey-yellow and grey-green mudstone layers have thin horizontal beddings (Fig. 2f), indicative of in-situ aeolian dune and lacustrine facies (e.g. Picard and High, 1981; Pye and Tsoar, 2009; Reading, 1996), respectively.

Based on the chronological frame established by paleomagnetic and ESR dating of two parallel sections (Sun D. et al., 2011a), the base of continental succession, the oldest insitu aeolian dune sand at $241 \mathrm{~m}$, the major colour transition from reddish to grey-yellow at $153 \mathrm{~m}$, and the top of the section of the HBS Section were dated at $\sim 4.2 \mathrm{Ma}, \sim 3.4 \mathrm{Ma}$, $\sim 2.8 \mathrm{Ma}$, and $\sim 0.99 \mathrm{Ma}$, respectively (Fig. 2). The HBS Section can be correlated with the Mazatagh Section (Sun D. et al., 2011a), KT1 Core (Zhang and Men, 2002), and KT2 Core (Xu et al., 2003) to the east (see section/drilling core locations in Fig. 1a), suggesting that the sedimentary record of the HBS Section reflects the broader paleo-environmental evolution of the central Tarim Basin.

Five hundred and thirty six samples were collected with an average sampling space of $0.85 \mathrm{~m}(\sim 6 \mathrm{kyr})$ for analysis of proxy indices. Ages of the collected samples were obtained by the linear interpolation between the ages of geomagnetic polarity boundaries (e.g. Sun D. et al., 2011a). Grain size was measured using a Malvern Mastersizer 2000 laser grainsize analyser, following the pre-treatment procedures of Konert and Vandenberghe (1997). Magnetic susceptibility was measured on a Bartington MS2 System with operating frequencies of $0.47 \mathrm{kHz}\left(\chi_{\mathrm{LF}}\right)$ and $4.7 \mathrm{kHz}\left(\chi_{\mathrm{HF}}\right)$, respectively. Frequency-depended magnetic susceptibility $\left(\chi_{\mathrm{FD}}\right)$ was obtained by the formula: $\chi_{\mathrm{FD}}(\%)=\left(\chi_{\mathrm{LF}}-\chi_{\mathrm{HF}}\right) \chi_{\mathrm{LF}} \times 100$ (Dearing, 1994). For colour measurement, the sample was firstly dried at natural temperature, then was crushed without destroying grain size, and finally it was measured on a
Konica-Minolta CM-700 colour meter. All the measurements were performed in the Key Laboratory of Western China's Environmental systems, Lanzhou University.

\section{Results}

\subsection{Grain-size variation and its paleo-environmental implications}

Grain size is closely linked to the processes and dynamics of transporting medium that carries grains, and thus, was frequently used in the paleo-environmental reconstructions as proxy for changes in property and potential energy of the transport medium (e.g. McCave et al., 1995; Porter, 2001; Ding et al., 2002; Duller et al., 2010; Vandenberghe, 2013). At the HBS Section, typical in-situ aeolian dune sand has a unimodal grain-size distribution with a well-sorted and symmetrical distributed sand saltation component (ca. 50$250 \mu \mathrm{m})($ Fig. 3a). Loess generally has a tri-modal grain-size distribution consisting of a short suspension dust component (ca. 20-60 $\mu \mathrm{m}$ ), a long suspension dust component (ca. 10$15 \mu \mathrm{m})$, and a minor portion of the ultrafine component (ca. $<2 \mu \mathrm{m}$ ) (Fig. 3b), representing storm dust, background dust (Sun D. et al., 2004; Vandenberghe, 2013), and pedogenic clay (Sun D. et al., 2011b), respectively. Lacustrine clay has a bimodal grain-size distribution that is composed of a well-sorted lacustrine suspension component (ca. 8-9 $\mu \mathrm{m}$ ) and a small portion of the utralfine component (ca. $<2 \mu \mathrm{m}$ ) (Fig. 3c); occasionally, it contains a poorly-sorted coarser component (ca. $30 \mu \mathrm{m}$ ) (Fig. 3d), which is interpreted as the aeolian saltation component in the lake sediments (e.g. Sly, 1978; Sun D. et al., 2002; Xiao et al., 2012). Fluvial sand has isolated features in the grain-size distribution and specific grain-size ranges, which are, respectively, the wellsorted saltation (ca. 250-400 $\mu \mathrm{m}$ ) and the poorly-sorted suspension (ca. 10-15 $\mu \mathrm{m}$ ) components (Fig. 3e; e.g. Middleton, 1976; Ashley, 1978; Bennett and Best, 1995). Whilst, the mixed sediment (e.g. wind reworking of fluvial deposits) has a polymodal grain-size distribution (Fig. 3f).

Mean size variations across the HBS Section are characterised by a pattern of high frequency fluctuations superimposed on an overall increasing trend (Fig. 4). The former one reflects the lithologic alternations between aeolian sand, loess, fluvial sand and lacustrine clay, and thus reveals the periodic environmental changes on orbital timescale. The latter one represents progressive enhancement in the potential energy to the transporting medium from 4.2-0.99 Ma.

\subsection{Variation in the ultrafine component proportion and its paleo-environmental implications}

Grain-size data from the HBS Section reveal an ultrafine component, with a consistent modal size of ca. $0.87 \mu \mathrm{m}$ and a variable proportion of 0.3 to $10 \%$, prevailed in the sequence (Fig. 3). In general, the ultrafine grains $(<2 \mu \mathrm{m})$ in 

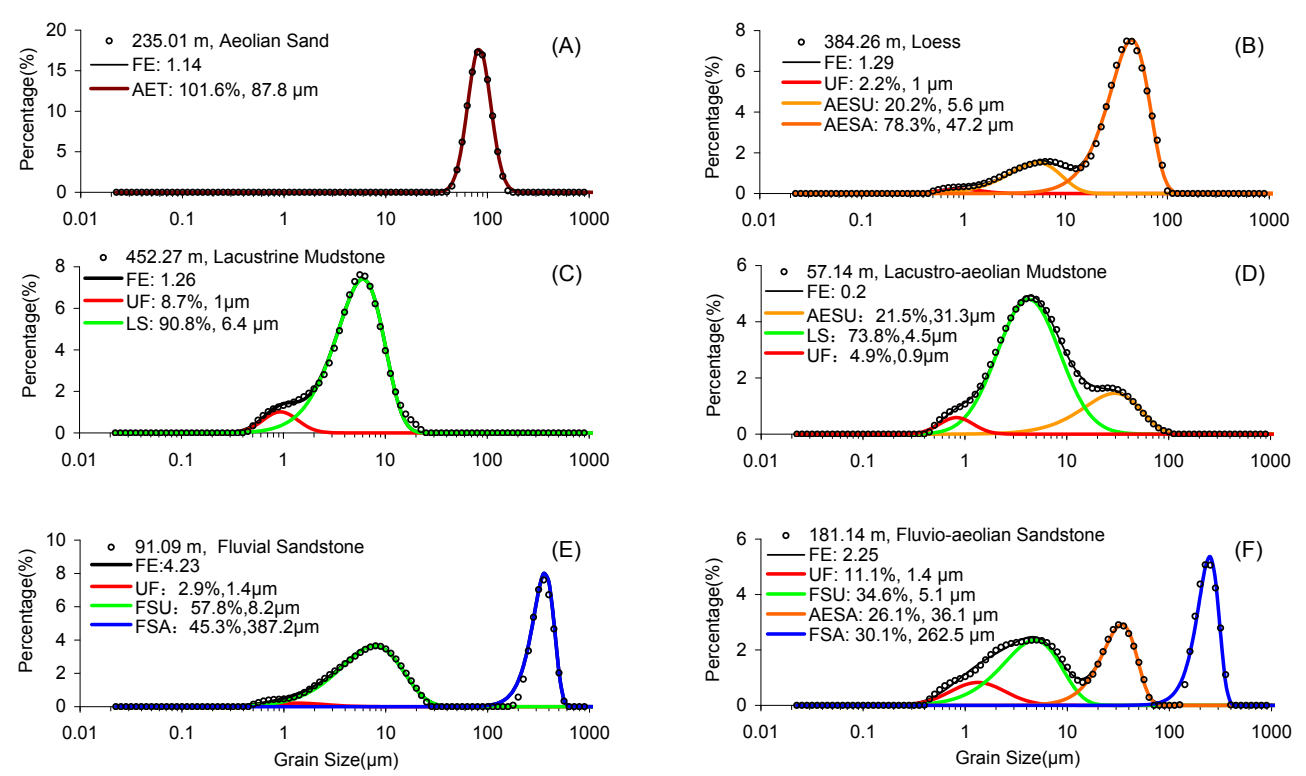

Fig. 3. Grain-size distribution of representative samples from the HBS section. The specific sedimentary components were partitioned and identified using the grain size distribution developed by Sun D. et al. (2002). Abbreviations: FE-fitting curve with error, UF-ultrafine component, AESU-aeolian suspension component, AESA-aeolian saltation component, AET-aeolian traction component, LS-lacustrain suspension component, FSU-fluvial suspension component, FSA-fluvial saltation component.

the nonmarine sediments are mainly composed of clay minerals (e.g. Sun D. et al., 2011b), which can be formed in two possible ways: (1) transported to the deposition sites as discrete grains and/or as attachments to large grains from the source region (Pye, 1987); (2) produced during the depositional processes (Paton, 1978; Liu, 1985; Bronger and Heinkele, 1989, 1990). The low degree of crystallinity in illite and the tempo-spatial variations of the ultrafine component suggest that the ultrafine component proportion in aeolian sediments is linked closely to the pedogenic processes (Sun D. et al., 2011b). By contrast, its variations in fluvial-lacustrine sediments may connected to the chemical weathering intensity (e.g. Chen et al., 2003; Lv et al., 2011; Wang X. et al., 2012) and/or the depositional processes in the lake, both of which are sensitive to climatic change. At the HBS Section, the ultrafine component proportion is systematic higher in lacustrine and fluvial sediments (ca. 5.99\%), and is lower in aeolian sand and loess (ca. 2.76\%), implying the soil moisture level played an important role in driving the variability of the ultrafine component proportion. At the HBS Section, the ultrafine component proportion increases gradually from $457-153 \mathrm{~m}$ (4.2-2.8 Ma), and subsequently decreases thereafter (2.8-0.9 Ma) (Fig. 4). The abrupt drop in the ultrafine component proportion at $153 \mathrm{~m}(2.8 \mathrm{Ma})$ reflects an enhancement in continental aridity.

\subsection{Colour reflectance variation and its paleo-environmental implications}

Colour is the most visualized property of the sediments, of which the red and grey-yellow have special paleoenvironmental implications. A red colour is ascribed to the presence of the mineral hematite $\left(\alpha-\mathrm{Fe}_{2} \mathrm{O}_{3}\right)$ that is formed in a hot and dry climate, while a yellow colour is associated with goethite $(\alpha-\mathrm{FeOOH})$, which is associated with a colder and more humid climate (e.g. Reading, 1996; Viscarra Rossel et al., 2006). Therefore, variations between reds and yellows may reflect the change of oxidation state of the Fe iron that is mostly controlled by temperature (e.g. Barrón and Torrent, 1987; Thompson and Bell, 1996; Yang et al., 2001; Sun D. et al., 2011c). Lightness, by contrast, is mainly connected to the change of organic matter regime, which in turn reflects the climate change (e.g. Reading, 1996). A cooler and drier climate causes a slower decomposition rate of the organic matter and produces a lighter colour (higher lightness) of the sediments, and vice visas. Therefore, lightness can be used as proxy index for the decomposition rate of the organic matter that is mostly affected by the soil moisture and temperature. Throughout the HBS Section, redness $(a *)$ shows increases gradual from 457-153 m, and decreases thereafter (Fig. 4). Whist, lightness $(L)$ exhibits an overall negative relationship with the redness (Fig. 4). The dramatic decrease in redness and increase in lightness at $153 \mathrm{~m}$ (2.8 Ma) suggest a significant climatic cooling and drying. 


\subsection{Magnetic susceptibility variation and its implications for wind intensity}

Magnetic susceptibility is a function of categories, concentration and particle size of the magnetic minerals, which may be of post-depositional or detrital origin (e.g. Dearing, 1994; Liu et al., 2013 and references therein). At the HBS Section, magnetic susceptibility show systematic variations with lithology. Aeolian sand yields the lowest values (ca. $5.6 \times 10^{-8} \mathrm{SI}$ ), loess has slightly higher values (ca. $7.63 \times 10^{-8} \mathrm{SI}$ ), and fluvial and lacustrine deposits have the highest values (ca. $11.17 \times 10^{-8} \mathrm{SI}$ ). These changes produced the high frequency fluctuations in the magnetic susceptibility curve (Fig. 4). By contrast, the long-term variations of magnetic susceptibilities in different sediments exhibit consistent increasing trends from the bottom to top. For instance, magnetic susceptibility of loess maintains the lowest values (ca. $7.06 \times 10^{-8} \mathrm{SI}$ ) in Unit 1 , then it increases to higher values (ca. $8.33 \times 10^{-8} \mathrm{SI}$ ) in Unite 2 , and finally reaches the highest values (ca. $12.16 \times 10^{-8} \mathrm{SI}$ ) in Unit 3. The similar trend between different sediments implies that unique forcing factor contributed to the long-term variation of magnetic susceptibility. Rock magnetic analysis indicates that the appearance of polydomain magnetite in Unit 3 played an important role in driving the magnetic enhancement (Sun D. et al., 2011a). The overall negative relationship between the long-term trends of magnetic susceptibility and frequency-depended magnetic susceptibility (a proxy for pedogenesis, see Sect. 3.5) (Fig. 4) suggests a limited contribution of the superparamagnetic ferrimagnets to the long-term variation of magnetic susceptibility. Since the wind intensity and/or the distance to the source regions are the main controlling factors affecting the concentration of the polydomain ferrimagnets (Begét and Hawkins, 1989; Chlachula, 2003; Zan et al., 2010), and because of the late Cenozoic sediments in the central Tarim Basin are proximal deposits (Zhu et al., 1980; Si et al., 2009), it is apparent that a higher magnetic susceptibility indicates a stronger intensity of the atmospheric circulation, and vice versa. Across the HBS Section, magnetic susceptibility increases upward from the bottom to top of the section (Fig. 4), implying a progressive strengthening in the atmospheric circulation. The dramatic increase in magnetic susceptibility at $153 \mathrm{~m}(2.8 \mathrm{Ma})$ reveals a significant intensified atmospheric circulation.

\subsection{Frequency-depended magnetic susceptibility variation and its paleo-environmental implications}

Frequency-depended magnetic susceptibility reflects the concentration of viscous-superparamagnetic ferrimagnets that is mostly produced during the pedogenesis processes after deposited (e.g. Dearing, 1994; Evans and Heller, 2001). Since soil moisture and temperature are the major contributors in the pedogenic process (e.g. Chamley, 1989), it is obviously that a low frequency-depended magnetic susceptibility

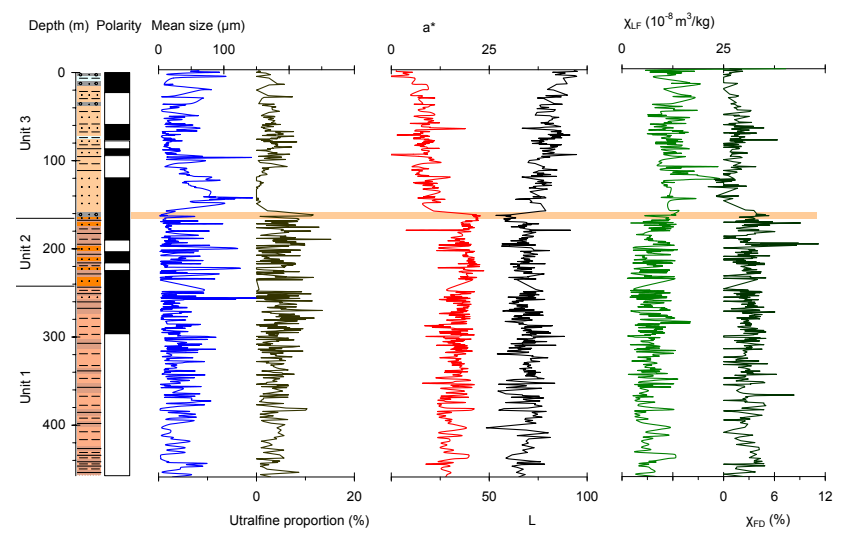

Fig. 4. Multi-proxy records of the HBS Section. The lithology types of the strata are the same as in Fig. 1. The grey bar indicates the boundary of the most dramatic changes in lithology and the multiproxy records.

value equals a weaker soil equals a dried and colder climate, and vice versa (e.g. Evans and Heller, 2001). The frequencydepended magnetic susceptibility thus can be use as a proxy for intensity of pedogenisis. Across the HBS Section, the frequency-depended magnetic susceptibility increases gradually from 457-153 m interval, and subsequently decreases thereafter (Fig. 4). The remarkable decrease in frequencydepended magnetic susceptibility at $153 \mathrm{~m}$ (2.8 Ma) yields an enhancement in continental aridity.

\section{Discussion and conclusion}

From 4.2-3.4 Ma, the central Tarim Basin was dominated by ephemeral fluvial-lacustrine environment under dry climate conditions, as indicated by the common occurrence of aeolian deposits and gypsum in the fluvial-lacustrine strata. Comparison of the multi-proxy indices of the HBS Section with those of the loess-paleosol sequences from the eastern CLP (see section locations at Fig. 1a) suggests a warmer and drier climate in the Tarim Basin than the CLP during this interval, owing to the HBS Section exhibit higher values in redness, and lower values in frequency-depended magnetic susceptibility and the ultrafine component proportion (Fig. 5). From 3.4 Ma onward, in-situ aeolian dune sand appeared and further developed in the sequence, suggesting the onset of the desertification in the central Tarim Basin initiated at this time. Nevertheless, the multi-proxy indices studied reveals a relatively warmer and more humid climate during 3.4$2.8 \mathrm{Ma}$, as redness, frequency-depended magnetic susceptibility and the ultrafine component proportion increases from 3.4 Ma to a maximum at 2.8 Ma. In addition, the increases in magnetic susceptibility and sedimentation rate (Sun D. et al., 2011a) represent an intensified atmospheric circulation and increased sedimentary supply, respectively, which are essential for the dune buildings. The lithologic boundary at $2.8 \mathrm{Ma}$ 
documents the first-order paleo-environmental change of the central Tarim Basin during the late Cenozoic. The change in sediment colour from deep red to light yellow reflects a significant climatic cooling and drying, the abrupt drop in frequency-depended magnetic susceptibility and the ultrafine component proportion indicates an enhancement in continental aridity, while, the rise in mean size and magnetic susceptibility reflects a strengthening in the wind intensity.

Geological and modelling evidence indicated the uplift of the Tibet Plateau and global cooling played the leading role in driving the Asian climatic changes during the late Cenozoic (e.g. Manabe and Terpstra, 1974; Ruddiman and Kutzbache, 1990; Manabe and Broccoli, 1990; Kutzbach et al., 1993; Ding et al., 1995; Li and Fang, 1999; An et al., 2001; Lu et al., 2010; Molnar et al., 2010; Chang et al., 2012; Miao et al., 2012). Multi-proxy indices reported here provide independent sedimentary and climatic evidence for the previous understandings: (1) the appearance of the oldest in-situ aeolian dune sand, at 3.4 Ma, is associated with an increase in sedimentation rate in the Tarim Basin (Sun D. et al., 2011a), and is correlated broadly with the accumulation of thick coarse-grained conglomerates in the north margin of the Kunlun Mountain arisen from the uplift of the northern Tibet Plateau (e.g. Huang and Chen, 1980; Zheng et al., 2000); (2) the climate of the central Tarim Basin during 3.4 to $2.8 \mathrm{Ma}$ was characterised by hot, relatively humid, and strengthened wind intensity, which can be correlated with the simultaneous intensification of both summer and winter eastern Asian monsoon over the CLP (e.g. An et al., 2001). It is difficult to attribute this climate pattern to the increasing of the volume of continental ice sheets during this interval (Fig. 5), as such an event should produce a weakening of the summer monsoon and strengthening of the winter monsoon in the Monsoon dominated area, as well as climatic cooling over western China (Prell and Kutzbach, 1992). We argued the continued growth of the Tibet Plateau along its northern and northeastern margins (e.g. An et al., 2001; Zheng et al., 2000) contributed to the regional climate changes. The remarkable cooling, enhanced aridity, and strengthening of the wind intensity in the central Tarim Basin at $2.8 \mathrm{Ma}$ is consistent with the climate changes over the CLP and the NP (Fig. 5, Sun D. et al., 2008; Sun Y. et al., 2010; Wang F. et al., 2012; Sun and An, 2005; Rea et al., 1998), which corresponds with the onset of the major Northern Hemisphere glaciation around 2.75 Ma (e.g. Ding et al., 1995; Lisiecki and Raymo, 2005), suggesting a causal relationship. Numerical modeling indicated that the expansion of the ice sheet would cause the southward shift of the polar front and the intensification of the Mongolia high and Siberia high system in North Asia, which in turn would result in a southward migration of the Westerlies and strengthening in the East Asian winter monsoon (Porter and An, 1995). The strengthened wind intensity, together with the enhanced continental aridity in the source regions, resulted in the further development of arid and semiarid environment over northwestern China.

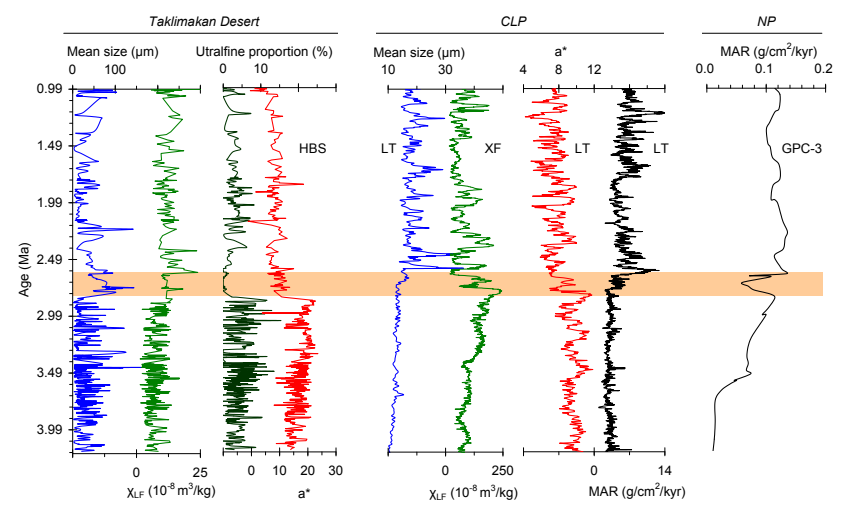

Fig. 5. Time series of the multi-proxy indices from the HBS Section and their correlation with those from the CLP (Sun D. et al., 2008; Sun Y. et al., 2010; Wang F. et al., 2012; Sun and An, 2005) and the NP (Rea et al., 1998). Sea section locations in Fig. 1a. The grey bar indicates the boundary of the most dramatic changes in lithology and the multi-proxy records. Abbreviations: HBS-Hongbaishan Section, LT-Lingtai Section, XF-Xifeng Section.

Multi-proxy evidence from the HBS Section suggests a fundamental environmental change, characterised by significant cooling, enhanced aridity, and intensified atmospheric circulation, occurred at $2.8 \mathrm{Ma}$ in the Tarim Basin. Good correlations between climate records from the source region and the downwind areas suggest a broadly consistent climate evolution over northwestern China during the late Cenozoic. We attribute the desertification in Tarim Basin to the uplift of the Tibet Plateau and to the Northern Hemisphere glaciations.

Acknowledgements. We would like to thanks Jef Vandenberghe and an anonymous reviewer for their comments and suggestions that helped improve the manuscript. We further thank Brian P. Kraatz for improve the English usage. Financial support for this research was provided by the National Natural Science Foundation of China (41272045 and 40625009), the National Basic Research Program of China (2012CB956102 and 2010CB833401), and the National Innovative Research Team Project (40121061).

Edited by: G. M. Ganssen

\section{References}

An, Z., Kutzbach, J., Prell, W., and Porter, S.: Evolution of Asian monsoons and phased uplift of the Himalaya-Tibetan plateau since Late Miocene times, Nature, 411, 62-66, 2001.

Aoki, I., Kurosaki, Y., Osada, R., Sato, T., and Kimura, F.: Dust storms generated by mesoscale cold fronts in the Tarim Basin, Northwest China, Geophys. Res. Lett., 32, L06807, doi:10.1029/2004GL021776, 2005.

Ashley, G. M.: Interpretation of polymodal sediments, The Journal of Geology, 86, 411-421, 1978. 
Barrón, V. and Torrent, J.: Origin of red-yellow mottling in a Ferric Acrisol of southern Spain, Zeitschrift für Pflanzenernährung und Bodenkunde, 150, 308-313, 1987.

Begét, J. and Hawkins, D.: Influence of orbital parameters on Pleistocene loess deposition in central Alaska, Nature, 337, 151-153, 1989.

Bennett, S. J. and Best, J. L.: Mean flow and turbulence structure over fixed, two-dimensional dunes: Implications for sediment transport and bedform stability, Sedimentology, 42, 491513, 1995.

Boggs, S.: Principles of sedimentology and stratigraphy, Prentice Hall Upper Saddle River, NJ, USA, 1995.

Bronger, A. and Heinkele, T.: Micromorphology and genesis of paleosols in the Luochuan loess section, China: pedostratigraphic and environmental implications, Geoderma, 45, 123-143, 1989.

Bronger, A. and Heinkele, T.: Mineralogical and clay mineralogical aspects of loess research, Quaternary Int., 7, 37-51, 1990.

Chamley, H.: Clay sedimentology, Springer-Verlag New York, 1989.

Chang, H., An, Z., Liu, W., Qiang, X., Song, Y., and Ao, H.: Magnetostratigraphic and palaeoenvironmental records for a Late Cenozoic sedimentary sequence drilled from Lop Nor in the eastern Tarim Basin, Global Planet. Change, 80-81, 113-122, 2012.

Chen, J. and Li, G.: Geochemical studies on the source region of Asian dust, Science China: Earth Science, 54, 1279-1301, 2011.

Chen, S., Wang, S, Jin, Z, and Shen, J.: Chemical Weathering and Environmental Change Records of the Last 2.8 Ma in the Central Tibetan Plateau, Geol. J. China Univ., 9, 19-29, 2003.

Chlachula, J.: The Siberian loess record and its significance for reconstruction of Pleistocene climate change in north-central Asia, Quaternary Sci. Rev., 22, 1879-1906, 2003.

Dearing, J.: Environmental magnetic susceptibility, Chi Publ, Kenilworth, UK, 1994.

Ding, Z., Liu, T., Rutter, N., Yu, Z., Guo, Z., and Zhu, R.: Icevolume forcing of East Asian winter monsoon variations in the past 800,000 years, Quaternary Res., 44, 149-159, 1995.

Ding, Z., Xiong, S., Sun, J., Yang, S., Gu, Z., and Liu, T.: Pedostratigraphy and paleomagnetism of a 7.0 Ma eolian loess-red clay sequence at Lingtai, Loess Plateau, north-central China and the implications for paleomonsoon evolution, Palaeogeogr. Palaeocli. Palaeoecol., 152, 49-66, 1999.

Ding, Z., Derbyshire, E., Yang, S., Yu, Z., Xiong, S., and Liu, T.: Stacked 2.6-Ma grain size record from the Chinese loess based on five sections and correlation with the deep-sea $\delta^{18} \mathrm{O}$ record, Paleoceanography, 17, 5-1-5-21, doi10.1029/2001PA000725, 2002.

Duller, R., Whittaker, A., Fedele, J., Whitchurch, A., Springett, J., Smithells, R., Fordyce, S., and Allen, P.: From grain size to tectonics, J. Geophys. Res., 115, F03022, doi:10.1029/2009JF001495, 2010.

Evans, M. and Heller, F.: Magnetism of loess/palaeosol sequences: recent developments, Earth-Sci. Rev., 54, 129-144, 2001.

Guo, Z., Ruddiman, W., Hao, Q., Wu, H., Qiao, Y., Zhu, R., Peng, S., Wei, J., Yuan, B., and Liu, T.: Onset of Asian desertification by $22 \mathrm{Myr}$ ago inferred from loess deposits in China, Nature, 416, 159-163, 2002.

Huang, J. and Chen, B.: On the Formation of Pliocene-Quaternary Molasses in the Tethys-Himalayan Tectonic Domain and Its Relation with the Indian Plate Motion, in: Scientific Papers on Ge- ology for international exchange, prepared for the 26th international geological congress 1 tectonic geology and geological mechanics, 1-14, 1980.

Konert, M. and Vandenberghe, J. E. F.: Comparison of laser grain size analysis with pipette and sieve analysis: a solution for the underestimation of the clay fraction, Sedimentology, 44, 523535, 1997.

Kutzbach, J., Prell, W., and Ruddiman, W.: Sensitivity of Eurasian climate to surface uplift of the Tibetan Plateau, The Journal of Geology, 177-190, 1993.

Li, J. and Fang, X.: Uplift of the Tibetan Plateau and nvironmental changes, Chinese Sci. Bull., 44, 2117-2124, 1999.

Lisiecki, L. and Raymo, M.: A Plio-Pleistocene stack of 57 globally distributed benthic $\delta^{18} \mathrm{O}$ records, Paleoceanography, 20, 522533, 2005.

Liu, Q., Roberts, A. P., Larrasoaña, J. C., Banerjee, S. K., Guyodo, Y., Tauxe, L., and Oldfield, F.: Environmental magnetism: Principles and applications, Rev. Geophys., 50, RG4002, doi:10.1029/2012RG000393, 2012.

Liu, T.: Loess and the Environment, China Ocean Press, Beijing, 251 pp., 1985.

Lu, H., Wang X., and Li L.: Aeolian sediment evidence that global cooling has driven late Cenozoic stepwise aridification in central Asia, Geological Society, London, Special Publications, 342, 2944, 2010.

Lv, Y., Zhao, J., Huang, W., Tao, S., and An, C.: Decomposition of the Grain-size Component and Its Climate Implication from Lake Barkol, Xinjiang, Acta Sedimentologica Sinica, 29, 134142, 2011.

Manabe, S. and Broccoli, A.: Mountains and arid climates of middle latitudes, Science, 247, 192-195, 1990.

Manabe, S. and Terpstra, T. B.: The effects of mountains on the general circulation of the atmosphere as identified by numerical experiments, J. Atmos. Sci., 31, 3-42, 1974.

McCave, I., Manighetti, B., and Beveridge, N. A. S.: Circulation in the glacial North Atlantic inferred from grain-size measurements, Nature, 374, 149-152, 1995.

Miao, Y., Herrmann, M., Wu, F., Yan, X., and Yang, S.: What controlled Mid-Late Miocene long-term aridification in Central Asia?-Global cooling or Tibetan Plateau uplift: A review, EarthSci. Rev., 112, 155-172, 2012.

Middleton, G. V.: Hydraulic interpretation of sand size distributions, The Journal of Geology, 84, 405-426, 1976.

Molnar, P., Boos, W., and Battisti, D.: Orographic controls on climate and paleoclimate of Asia: thermal and mechanical roles for the Tibetan Plateau, Annu. Rev. Earth Planet. Sci., 38, 77-102, 2010.

Paton, T. R.: The formation of soil material, George Allen and Uniwin Press, London, 143 pp., 1978.

Picard, M. D. and High J.: Physical stratigraphy of ancient lacustrine deposits, in: Recognition of Ancient Sedimentary Environments, edited by: Rigby, J. K. and Hamblin, W. K., 16, Soc. Econ. Paleontol. Mineral., Spec. Publ., 108-145, 1981.

Porter, S.: Chinese loess record of monsoon climate during the last glacial-interglacial cycle, Earth-Sci. Rev., 54, 115-128, 2001.

Porter, S. and An, Z.: Correlation between climate events in the North Atlantic and China during the last glaciations, Nature, 375, 305-308, 1995. 
Prell, W. L. and Kutzbach, J. E.: Sensitivity of the Indian monsoon to forcing parameters and implications for its evolution, Nature, 360, 647-652, 1992.

Pye, K.: Aeolian dust and dust deposits, Academic Press Londres, 1987.

Pye, K. and Tsoar, H.: Aeolian sand and sand dunes, Springer, 2009.

Qiang, X., An, Z., Song, Y., Chang, H., Sun, Y., Liu, W., Ao, H., Dong, J., Fu, C., Wu, F., Lu, F., Cai, Y., Zhou, W., Cao, J., Xu, X., and Ai, L.: New eolian red clay sequence on the western Chinese Loess Plateau linked to onset of Asian desertification about 25 Ma ago, Science China: Earth Sciences, 54, 1-9, 2011.

Ramstein, G., Fluteau, F., Besse, J., and Joussaume, S.: Effect of orogeny, plate motion and land-sea distribution on Eurasian climate change over the past 30 million years, Nature, 386, 788795, 1997.

Rea, D., Leinen, M., and Janecek, T.: Geologic approach to the long-term history of atmospheric circulation, Science, 227, 721725, 1985.

Rea, D., Snoeckx, H., and Joseph, L.: Late Cenozoic eolian deposition in the North Pacific: Asian drying, Tibetan uplift, and cooling of the northern hemisphere, Paleoceanography, 13, 215-224, 1998.

Reading, H.: Sedimentary environments: processes, facies, and stratigraphy, Wiley-Blackwell, 1996.

Ruddiman, W. F. and Kutzbach, J. E.: Late Cenozoic plateau uplift and climate change, Transactions of the Royal Society of Edinburgh: Earth Sciences, 81, 301-314, 1990.

Si, J., Li, H., Pei, J., and Pan, J.: Uplift of Northwest Margin of Tibetan Plateau: Indicated by Zircon LA ICP-MS U-Pb Dating of Conglomerate from Mazartagh, Tarim Basin, J. Earth Sci., 20, 401-416, 2009.

Sly, P. G.: Sedimentary processes in lakes, in:Lakes: Chemistry, Geology, Physics, edited by: Lerman, A., Springer, New York, 6589, 1978.

Sun, D., Shaw, J., An, Z., Cheng, M., and Yue, L.: Magnetostratigraphy and paleoclimatic interpretation of a continuous $7.2 \mathrm{Ma}$ Late Cenozoic eolian sediments from the Chinese Loess Plateau, Geophys. Res. Lett., 25, 85-88, 1998.

Sun, D., Bloemendal, J., Rea, D., Vandenberghe, J., Jiang, F., An, Z., and Su, R.: Grain-size distribution function of polymodal sediments in hydraulic and aeolian environments, and numerical partitioning of the sedimentary components, Sediment. Geol., 152, 263-277, 2002.

Sun, D., Bloemendal, J., Rea, D., An, Z., Vandenberghe, J., Lu, H., $\mathrm{Su}, \mathrm{R}$., and Liu, T.: Bimodal grain-size distribution of chinese loess, and its palaeoclimatic implications, Catena, 55, 325-340, 2004.

Sun, D., Su, R., Bloemendal, J., and Lu, H.: Grain-size and accumulation rate records from Late Cenozoic aeolian sequences in northern China: Implications for variations in the East Asian winter monsoon and westerly atmospheric circulation, Palaeogeogr. Palaeocli. Palaeoecol., 264, 39-53, 2008.

Sun, D., Bloemendal, J., Yi, Z., Zhu, Y., Wang, X., Zhang, Y., Li, Z., Wang, F., Han, F., and Zhang, Y.: Palaeomagnetic and palaeoenvironmental study of two parallel sections of late Cenozoic strata in the central Taklimakan Desert: Implications for the desertification of the Tarim Basin, Palaeogeogr. Palaeocli. Palaeoecol., 300, 1-10, 2011a.
Sun, D., Su, R., Li, Z., and Lu, H.: The ultrafine component in Chinese loess and its variation over the past 7.6 Ma: implications for the history of pedogenesis, Sedimentology, 58, 916-935, $2011 \mathrm{~b}$.

Sun, D., Zhang, Y., Han, F., Zhang, Y., Yi, Z., Li, Z., Wang, F., Wu, S., and Li, B.: Magnetostratigraphy and palaeoenvironmental records for a Late Cenozoic sedimentary sequence from Lanzhou, Northeastern margin of the Tibetan Plateau, Global Planet. Change, 76, 106-116, 2011c.

Sun, J., Ye, J., Wu, W., Ni, X., Bi, S., Zhang, Z., Liu, W., and Meng, J.: Late Oligocene-Miocene mid-latitude aridification and wind patterns in the Asian interior, Geology, 38, 515-518, 2010.

Sun, Y. and An, Z.: Late Pliocene-Pleistocene changes in mass accumulation rates of eolian deposits on the central Chinese Loess Plateau, J. Geophys. Res., 110, D23101, doi:10.1029/2005JD006064, 2005.

Sun, Y., An, Z., Clemens, S., Bloemendal, J., and Vandenberghe, J.: Seven million years of wind and precipitation variability on the Chinese Loess Plateau, Earth Planet. Sci. Lett., 297, 525-535, 2010.

Sun, Y., He, L., Liang, L., and An, Z.: Changing color of Chinese loess: Geochemical constraint and paleoclimatic significance, J. Asian Earth Sci., 40, 1131-1138, 2011.

Thompson, J. and Bell, J.: Color index for identifying hydric conditions for seasonally saturated mollisols in Minnesota, Soil Sci. Soc. Am. J., 60, 1979-1988, 1996.

Vandenberghe, J.: Grain size of fine-grained windblown sediment: A powerful proxy for process identification, Earth-Sci. Rev., 121, 18-30, 2013.

Viscarra Rossel, R., Minasny, B., Roudier, P., and McBratney, A.: Colour space models for soil science, Geoderma, 133, 320-337, 2006.

Wang, F., Sun, D., Guo, F., Wang, X., Li, Z., Zhang, Y., Li, B., and $\mathrm{Wu}, \mathrm{S}$.: Quantitative reconstruction of paleo-temperature and paleo-precipitation of Lingtai profile in Loess Plateau during the past 7 Ma, J. Earth Environ., 3, 791-791, 2012.

Wang, X., Sun, D., Wang, F., Li, B., and Wu, S.: The ultrafine component record from the late Cenozoic sequence in the central Tarim basin and its palaeoclimatic implication, Mar. Geol. Quatern. Geol., 32, 143-151, 2012.

Washington, R., Todd, M., Middleton, N., and Goudie, A.: Duststorm Source Areas Determined by the Total Ozone Monitoring Spectrometer and Surface Observations, Ann. Assoc. Am. Geogr., 93, 297-313, 2003.

Xiao, J., Chang, Z., Fan, J., Zhou, L., Zhai, D., Wen, R., and Qin, X.: The link between grain-size components and depositional processes in a modern clastic lake, Sedimentology, 59, 1050-1062, 2012.

Xu, J., Yang, Z., Zheng, H., Zhang, J., Lin, F., and Shi, Y.: Quaternary magnetic stratigraphy of the Tarim Basin, J. Stratigr., 27, 256-261, 2003.

Yang, S., Fang, X., Li, J., An, Z., Chen, S., and Hitoshi, F.: Transformation functions of soil color and climate, Science in China Series D: Earth Sciences, 44, 218-226, 2001.

Yong, T., Shan, J., and Wang, S.: Several geological issues about the Marzartag-together with the geological age of the Taklamakan desert, Xinjiang Petroleum Geol., 4, 1-9, 1983.

Zan, J., Fang, X., Yang, S., Nie, J., and Li, X.: A rock magnetic study of loess from the West Kunlun Mountains, J. Geophys. Res., 115, B10101, doi:10.1029/2009JB007184, 2010. 
Zhang, H. and Men, G.: Stratigraphic subdivision and climatic change of the Quaternary of the center Taklimakan Deaert, Xinjiang Geol., 20, 256-261, 2002.

Zhang, X., Gong, S., Zhao, T., Arimoto, R., Wang, Y., and Zhou, Z.: Sources of Asian dust and role of climate change versus desertification in Asian dust emission, Geophys. Res. Lett., 30, 2272, doi:10.1029/2003GL018206, 2003.
Zhang, Z., Wang, H., Guo, Z., and Jiang, D.: What triggers the transition of palaeoenvironmental patterns in China, the Tibetan Plateau uplift or the Paratethys Sea retreat?, Palaeogeogr. Palaeocli. Palaeoecol., 245, 317-331, 2007.

Zheng, H., Powell, C., An, Z., Zhou, J., and Dong, G.: Pliocene uplift of the northern Tibetan Plateau, Geology, 28, 715-718, 2000.

Zhu, Z., Wu, Z., Liu, S., and Di, X: An outline on Chinese Deserts, Science Press, Beijing, 107 pp., 1980. 